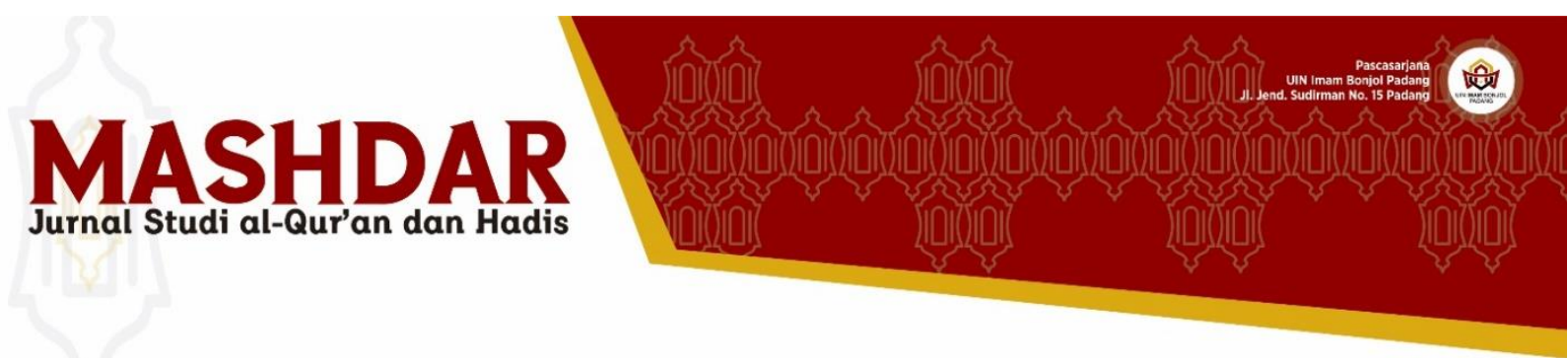

\title{
Analisis Kemampuan Membaca Al-Qur'an Dalam Perspektif Sosiologi Pengetahuan
}

\section{Fitriyah Mahdali}

Institut Agama Islam al-Qolam Malang email: fitriyahmahdaly@gmail.com

\begin{abstract}
MAN 1 Malang is one of the formal educational institutions in Malang regency under the auspices of the Ministry of Religious Affairs. The vision and mission includes forming students who are religious and carry out religious activities in daily life. One indicator that must be met to become a religious individual is to be able to understand and carry out the contents contained in the holy book of the Qur'an. A necessity to be able to understand the contents of a person must be able to read it. With this background, this study focuses on three problems: (1) How to portray the ability of MAN students in reading the Qur'an, (2) What is the process of internalizing students in their environment, especially those who cannot read the Qur'an, and (3) How is the principal's effort in dealing with students who cannot read the Qur'an. This research is a study of the sociology of education. The method used in this research is descriptive qualitative, which is one type of research that aims to describe and understand certain phenomena. The approach used is the sociology of knowledge. Namely revealing a phenomenon using knowledge that develops in the wider community. The findings in this study are (1) Of the 952 students of MAN 1 Malang, there were 49 students who could not read the Qur'an. This phenomenon is contrary to the existing vision and mission. (2) The internalization process greatly affects the ability of students to read the Qur'an. These factors include family support, environmental conditions, family conditions and student internal factors. (3) Efforts made by MAN 1 Malang to succeed in its vision and mission are to hold a Qur'an reading guidance program for students who have not been able to.
\end{abstract}

Keywords: Al-Qur'an; Internalization; Sociology of Knowledge

(P-ISSN: 2685-1547; E-ISSN: 2685-1555)

Pemalink:

Avaible on https://ejournal.uinib.ac.id/jurnal/index.php/mashdar 


\section{PENDAHULUAN}

Lembaga pendidikan di Indonesia terbagi menjadi tiga, yaitu lembaga formal, lembaga non formal dan lembaga informal. Lembaga formal meliputi sekolah dengan jenjang mulai Pendidikan Anak Usia Dini, Taman Kanak-kanak, Sekolah Dasar, Sekolah Menengah, Sekolah Atas dan sekolah tinggi atau yang biasa disebut dengan kampus. Lembaga non formal merupakan pesantren dan taman pendidikan Al-Qur'an yang diselenggarakan di musholla dan rumahrumah. Sedangkan lembaga informal merupakan pendidikan yang didapat dari keluarga dan lingkungan sekitar. ${ }^{1}$

Lembaga pendidikan tersebut secara keseluruhan memiliki dan mengajarkan pendidikan agama kepada masing-masing peserta didik guna untuk membentuk perilaku siswa yang sesuai dengan norma dan aturan yang berlaku. Akan tetapi, setiap lembaga pendidikan memiliki kadar ukuran yang berbeda-beda dalam menerapkan pembelajaran agama. Sekolah yang basisnya umum dengan lembaga pendidikan yang berbasis Madrasah jelas memiliki kurikulum pembelajaran yang berbeda. Jika pada Sekolah Menengah Atas (SMA) pendidikan agama disatukan dalam mata pelajaran PAI maka lain dengan Madrasah Aliyah (MA) yang memiliki banyak mata pelajaran agama seperti Fiqh. Aqidah Akhlaq, Al-Qur'an dan Hadist, Sejarah Kebudayaan Islam, dan lain sebagainya.

Dalam pendidikan agama, kita akan banyak menemukan literatur pendidikan yang menggunakan Bahasa Arab serta kajian-kajian berupa Hadist dan Ayat-ayat Al-Qur'an. Rasulullah membekali umat manusia dengan Al-Qur'an dan Hadist agar dijadikan sebagai pedoman hidup yang

\footnotetext{
${ }^{1}$ Hasbullah, Dasar-dasar Ilmu Pendidikan, (Jakarta : Raja Grafindo Persada, 1999), hlm. 47
}

mampu mengarahkan ke jalan yang benar. Dengan demikian Al-Qur'an merupakan pendidikan mendasar yang harus dimiliki oleh siswa sebab pengetahuan dalam membentuk moral dan perilaku manusia yang sesuai norma sudah dijelaskan di dalam Al-Qur'an.

Sebelum mempelajari Al-Qur'an sebagai sumber pengetahuan, akan lebih mudah jika peserta didik memahami bagaimana cara membaca Al-Qur'an dengan kaidah yang baik dan benar. Namun, yang menjadi permasalahan mendasar saat ini adalah bagaimana jika peserta didik dari lembaga pendidikan yang notabenenya Madrasah memiliki sedikit keterlambatan dalam memahami Baca Tulis Al-Qur'an. Umumnya, seseorang akan mempelajari ilmu tajwid untuk memahami bagaimana kaidah membaca Al-Qur'an dengan benar, mempelajari Makhorijul Huruf serta Shifatul Huruf agar bacaannya tepat dan tidak menyimpang dari arti yang sebenarnya. Setelah memiliki kemampuan membaca AlQur'an maka akan lebih mudah untuk mempelajari apa yang dijelaskan di dalamnya.

Paparan tersebut mengarah pada fakta yang ditemukan oleh peneliti bahwa di MAN 1 Malang yang merupakan satusatunya Madrasah Aliyah Negeri yang ada di kecamatan Gondanglegi memiliki beberapa siswa-siswi yang belum menguasai baca tulis Al-Qur'an dengan baik. $^{2}$ Padahal, lazimnya siswa-siswi Madrasah lebih menguasai pendidikan agama dibandingkan siswa-siswi diluar Madrasah. Secara umum, kemampuan baca tulis Al-Qur'an siswa-siswi Madrasah tidak diragukan lagi. Faktanya dari 952 siswasiswi MAN 1 Malang ada beberapa siswa/i yang dikategorikan belum memiliki kemampuan Baca Tulis Al-Qur'an dengan

\footnotetext{
${ }^{2}$ Hasil Observasi peneliti di MAN 1 Malang pada tanggal 15 Mei 2019
} 
baik dan benar berdasarkan tes yang sudah dilakukan.

Berdasarkan fakta tersebut, peneliti mengkaji dari sudut pandang sosiologi pendidikan. Secara umum, sosiologi merupakan suatu ilmu pengetahuan yang mempelajari tentang masyarakat secara keseluruhan, yaitu mempelajari tentang hubungan manusia antar manusia, hubungan manusia dengan kelompok, hubungan kelompok antar kelompok, baik secara material maupun formal, baik secara statis maupun dinamis. Sosiologi mempelajarai setiap gejala umum yang terjadi pada manusia, oleh karena itu sosiologi mencakup segala aspek yang ada dalam kehidupan manusia. Sedangkan sosiologi pendidikan merupakan suatu ilmu pengetahuan yang mempelajari bagaimana proses belajar dan mempelajari antar satu individu dengan individu yang lainnya. ${ }^{3}$

Dalam ranah sosiologi pendidikan, yang menjadi sasaran utama adalah peserta didik dan lingkungan sosialnya. Lingkungan sosial jelas dapat mempengaruhi proses belajar peserta didik. Sosiologi pendidikan tidak melulu berhubungan dengan tujuan pendidikan, kurikulum, pengukuran serta metodenya akan tetapi juga berhubungan dengan sekolah dan seluruh masyarakat. Salah satu lingkungan sosial peserta didik akan berhubungan dengan sikap orang tuanya yang menjadi penunjang utama dalam keluarga, perbedaan keinginan antara orang tua dan anak. Misalnya orang tua menginginkan anaknya menjadi seseorang yang berbakat dalam bidangbidang tertentu. ${ }^{4}$

Keluarga merupakan salah satu pusat pendidikan bagi seorang anak. Secara tidak langsung, otak anak akan merekam apa saja yang menjadi kebiasaannya sehari-hari.

\footnotetext{
${ }^{3}$ Abu Ahmadi, Sosiologi Pendidikan, (Surabaya : PT Bina Ilmu, 1982), hlm. 16
}

Adakah keluarga menjadi faktor utama penyebab anak tidak mampu belajar dengan baik terutama belajar membaca AlQur'an, atau karena faktor keyakinankeyakinan tertentu yang sudah tertanam dalam diri anak sejak dini. Lingkungan keluarga yang baik tentu akan membentuk karakter anak yang baik, begitupun sebaliknya. Dalam dunia pendidikan, peran orang tua sangat signifikan dengan kelangsungan proses belajar anak. Ketika ada dalam lingkungan keluarga maka orang tua memiliki peran utama untuk mendidik seorang anak, akan tetapi ketika berada di lingkungan sekolah guru merupakan pendidik yang utama. Meskipun demikian keduanya saling berhubungan.

Selain dalam lingkungan keluarga, kondisi lingkungan sekitar tempat tinggal anak juga mempengaruhi bagaimana dia bersikap. Kondisi lingkungan masyarakat yang baik dan kondusif akan mempengaruhi dan menciptakan perilaku yang baik pula dalam diri manusia. Dalam kasus ini, peneliti akan mengkaji aspek sosial siswa-siswi MAN 1 Malang yang belum memiliki kemampuan membaca AlQur'an dengan baik. Apakah ada ketimpangan dan penyimpangan sosial dalam lingkungannya terutama keluarga yang menjadi faktor utama keterlambatan seorang anak untuk memahami baca tulis Al-Qur'an, internalisasi nilai apakah yang sudah mereka lakukan sehingga mempengaruhi pola berfikir dan bersikap seorang anak. Serta upaya apa yang sudah dilakukan oleh pihak sekolah untuk meminimalisir keadaan tersebut.

\section{PERSPEKTIF METODOLOGI}

Penelitian ini merupakan penelitian lapangan atau field research karena peneliti langsung terjun ke lapangan untuk

\footnotetext{
${ }^{4}$ Abu Ahmadi, Sosiologi, hlm. 16
} 
mengkaji lebih dalam fakta-fakta yang telah ditemukan sebelumnya. Penelitian lapangan secara intensif mempelajari latar belakang dan keadaan interaksi unit sosial, individu atau kelompok. ${ }^{5}$ Obyek dalam penelitian ini adalah siswa-siswi MAN 1 Malang.

Berdasarkan jenisnya, penelitian ini merupakan penelitian kualitatif dengan pendekatan deskriptif eksploratif. Dalam penelitian kualitatif data yang disajikan bukan berupa angka akan tetapi berupa kata-kata dan deskripsi, oleh karena itu pendekatan dalam penelitian ini menggunakan pendekatan deskriptif. Pendekatan deskriptif merupakan pengamatan dan penelitian terhadap suatu fenomena tertentu yang diperoleh peneliti dari suatu populasi. Pendekatan deskriptif tidak mengharuskan adanya pengujian terhadap hipotesis tertentu, akan tetapi menggambarkan apa adanya tentang satu variable atau keadaan dilapangan. Sedangkan eksploratif merupakan jenis penelitian yang memiliki tujuan untuk menemukan dan mengeksplorasi sesuatu yang baru berupa pengelompokan suatu gejala, fakta dan penyakit tertentu. ${ }^{6}$ Penelitian ini bertujuan untuk menggambarkan keadaan suatu fenomena tanpa dimaksudkan untuk menguji sebuah hipotesis.

Dalam penelitian kualitatif, peneliti merupakan instrumen utama yang dibutuhkan dalam sebuah penelitian. Kehadiran peneliti di lapangan merupakan sebuah instrumen penelitian yang akan melakukan observasi, wawancara dan pengambilan dokumen.7 Oleh karena itu, peneliti sebagai instrumen penelitian juga harus di validasi seberapa jauh peneliti siap melakukan penelitian dan terjun ke lapangan. Validasi terhadap peneliti sebagai instrumen penelitian meliputi seberapa jauh pemahaman terhadap metode penelitian kualitatif, penguasaan wawasan dan juga kesiapan peneliti memasuki obyek penelitian.

Populasi dalam penelitian ini merupakan seluruh siswa/i MAN 1 Malang yang tidak dapat membaca Al-Qur'an. Sedangkan sampel dalam penelitian ini dipilih secara purposive dan bersifat snowball sampling. Peneliti memilih sumber data yang ada di lapangan yang sesuai dengan tujuan peneliti untuk menggali informasi. Sumber data bisa diperoleh dengan data tertulis dan data tidak tertulis. Data tertulis merupakan dokumen-dokumen sekolah yang sudah tersedia dan terarsip dengan rapi yang bisa memberikan informasi bagi peneliti, sedangkan data tidak tertulis merupakan hasil wawancara terhadap key informan yang dianggap mampu memberikan informasi.

Untuk mengumpulkan data pada penelitian ini, peneliti menggunakan triangulasi teknik. Triangulasi teknik berarti peneliti mengumpulkan data yang diperlukan dengan menggunakan teknik pengumpulan data yang berbeda-beda. Triangulasi teknik merupakan gabungan dari ketiga teknik diatas. ${ }^{8}$ Ketiga teknik yang digunakan untuk mengumpulkan data tersebut adalah observasi, wawancara dan dokumentasi. Teknik analisis data adalah suatu proses mencari dan menyusun secara sistematis data yang diperoleh dari hasil observasi, wawancara, dokumentasi, analisis suatu data, melakukan sistesa dan membuat kesimpulan sehingga mudah

\footnotetext{
${ }^{7}$ Sugiyono, Metode Penelitian Pendidikan, (Bandung : Alfabeta Bandung : 2016). Hlm.305

${ }^{8}$ Sugiyono, Metode Penelitian Pendidikan, (Bandung : Alfabeta Bandung : 2016). Hlm.309
} 
untuk dipahami diri sendiri dan orang lain. ${ }^{9}$ Dalam penelitian kualitatif, analisis data dapat dilakukan dengan tiga cara reduksi data, penyajian data dan verifikasi data.

\section{PEMBAHASAN}

\section{Konsep Kemampuan Membaca Al-Qur'an}

Sebagaimana diketahui secara umum, Al-Qur'an adalah firman Allah yang diturunkan kepada Nabi Muhammad SAW melalui malaikat jibril sebagai petunjuk dan pedoman hidup manusia. Al-Qur'an diturunkan dengan menggunakan Bahasa Arab, baik dari segi lafal maupun uslubnya. ${ }^{10} \mathrm{Al}$-Qur'an diturunkan menggunakan Bahasa Arab sebab beberapa keistimewaan yang dimilikinya, salah satunya adalah Bahasa Arab merupakan bahasa tertua yang ada di muka bumi sebab Bahasa Arab berkembang mulai Nabi Adam AS dan Siti Hawa, Bahasa Arab merupakan bahasa yang paling banyak memiliki kosa kata yang jarang ditemui pada bahasa lainnya, serta bahasa inilah yang memiliki tingkat kesusastraan paling tinggi. ${ }^{11}$

Sebagai pedoman hidup, tentu umat manusia harus mempelajarinya agar tidak tersesat pada akhirnya. Agar tidak terbawa oleh bujuk rayu syaithan, Al-Qur'an wajib dikaji, dipahami, dihayati dan kemudian diamalkan. Sebab Al-Qur'an akan menjadi penolong bagi yang istiqomah dalam membacanya. Hal ini sesuai dengan hadist Nabi yang artinya :

"Bacalah Al-Qur'an, sesungguhnya ia datang pada hari kiamat sebagai pemberi syafa'at bagi orang yang membacanya" (HR. Muslim)

\footnotetext{
9 Sugiyono, Metode Penelitian Kuantitatif, Kualitatif dan RED, (Bandung : Alfabeta, 2001), hlm. 244

10 Said Agil Husin Al-Munawwar, Al-Qur'an Membangun Tradisi Keshalehan Hakiki, (Jakarta : Ciputat Pers, 2002), hlm. 3

11 Al-Qattan Manna, Studi Ilmu-ilmu Al-Qur'an, (Surabaya : CV Rasma Putra, 2009), hlm. 379
}

Kemampuan merupakan kecakapan, kesanggupan dan kekuatan seorang individu untuk berusaha sendiri. ${ }^{12}$ Sedangkan pengertian membaca adalah proses mengubah sebuah bentuk lambang/tulisan/tanda menjadi sebuah bacaan yang kemudian dapat dipahami isinya. ${ }^{13}$ Berdasarkan pengertian tersebut dapat disimpulkan bahwa membaca merupakan kegiatan memahami suatu bacaan dengan melisankan yang sudah tertulis.

Sedangkan pengertian Al-Qur'an menurut para ahli adalah wahyu Allah yang diturunkan kepada Nabi Muhammad yang ditulis berbentuk mushaf. ${ }^{14}$ Menurut ahli tafsir Al-Qur'an yang lain, Al-Qur'an merupakan kalamullah atau firman Allah yang diturunkan kepada Nabi Muhammad SAW dan bagi yang membacanya merupakan ibadah. ${ }^{15}$ Serta masih banyak lagi pengertian Al-Qur'an yang senada dengan yang sudah disebutkan diatas.

Dari pengertian diatas dapat disimpulkan bahwa kemampuan membaca Al-Qur'an merupakan suatu kecakapan seorang individu untuk membaca AlQur'an dengan baik dan benar sesuai dengan kaidah yang berlaku. Untuk memahami isi dari suatu maksud, maka seseorang diwajibkan terlebih dahulu untuk membaca, begitupun dengan $\mathrm{Al}$ Qur'an. Agar memahami suatu maksud dan tujuan yang termaktub dalam Al-Qur'an sebagai pedoman hidup manusia, maka seseorang harus membacanya terlebih dahulu.

12 B. Suryosubroto, Proses Belajar Mengajar di Sekolah, (Jakarta : Rineka Cipta, 2009), hlm. 16

${ }^{13}$ Dalman, Keterampilan Membaca, (Jakarta : PT Raja Grafindo Persada, 2013), hlm. 1

${ }^{14}$ Hasbi Ash Shiddiqy, Sejarah dan Pengantar Ilmu Al-Qur'an/Tafsir, (Jakarta : PT Bulan Bintang, 1992), hlm. 1

${ }^{15}$ Hasbi Ash Shiddiqy, Sejarah, hlm. 17 
1. Indikator Kemampuan Membaca AlQur'an

Adapun seseorang dapat dikatan mampu membaca Al-Qur'an dengan baik dan benar sesuai kaidah yang berlaku yakni apabila seorang tersebut mampu membaca dengan memenuhi aspek-aspek berikut ${ }^{16}$ :

a. Tajwid

Dalam membaca Al-Qur'an seseorang harus memahami kaidah ilmu tajwid. Tajwid merupakan suatu ilmu yang mempelajari tentang tempat keluarnya huruf (Makharijul Huruf), sifat-sifat huruf (Shifatul Huruf) serta bacaan-bacaannya. Ilmu tajwid bertujuan agar seseorang dapat membaca Al-Qur'an dengan benar dan fasih sesuai dengan ajaran Nabi Muhammad SAW dan menghindari terjadinya kesalahan dalam AlQur'an.17

Hukum mempelajari ilmu tajwid menurut para ulama' adalah Fardhu Kifayah sedangkan membaca AlQur'an dengan menerapkan kaidah tajwid hukumnya adalah Fardhu 'Ain yakni wajib bagi masing-masing individu yang membaca Al-Qur'an. Oleh sebab itu, menjadi wajib bagi setiap umat muslim untuk mempelajari ilmu tajwid guna menghindari kesalahan dalam membaca Al-Qur'an.

Dalam penerapan ilmu tajwid, Nabi Muhammad SAW merupakan contoh pendidik yang dapat dijadikan sebagai teladan. Nabi Muhammas SAW merupakan seorang guru dan pendidik yang mengajarkan Al-Qur'an lengkap dengan penerapan ilmu tajwid terutama kepada anak yang masih kecil. Berkenaan dengan ini ruang

16 Al-Qattan Manna, Studi Ilmu-ilmu Al-Qur'an, (Surabaya : CV Rasma Putra, 2009), hlm. 367

17 Ahmad Soenarto, Pelajaran Tajwid Praktis dan Lengkap, (Jakarta : Bintang Terang), hlm. 6 lingkup ilmu tajwid yang akan dipelajari meliputi sifat-sifat huruf, makhraj huruf, bacaan-bacaan yang ada dalam ilmu tajwid, tanda waqaf serta yang lainnya. ${ }^{18}$

b. Makharijul Huruf

Makahrijul Huruf atau tempat keluarnya huruf berbeda-beda sesuai dengan jenis hurufnya. Seorang peserta didik tidak dapat membedakan suatu huruf tanpa tau darimana tempat keluarnya huruf tersebut. Penting sekali mengetahui perbedaan antara satu huruf dengan huruf lainnya agar terhindar dari kesalahan membaca, jika bacaan tersebut salah maka akan merubah arti yang sebenarnya.

Sebagai contoh pada permulaan surat At-Tin, kata pertama pada surat tersebut jika dibaca "Wa at-Thin" yang artinya demi buah tiin, jika seseorang tidak dapat membedakan hurufnya dan kemudian terbaca "Wa ats-Siin" maka artinya akan berubah menjadi demi tanah. Ketika kita membaca AlQur'an dengan kesalahan-kesalahan secara terus menerus, maka bukan nilai ibadah yang didapatkan akan tetapi sebaliknya, sebab ketika tidak mengetahui suatu ilmu diwajibkan bagi seseorang untuk mempelajarinya. Adapun tempat keluarnya huruf meliputi ${ }^{19}$ :

1) Al-Halq (tenggorokan) meliputi : Pangkal tenggorokan ( odan I), tengah tenggorokan ( $\varepsilon$ dan $\tau$ ) dan ujung tenggorokan ( $\dot{\varepsilon}$ dan $\dot{\tau})$

2) Al-Lisan (lidah) meliputi : Pangkal lidah dengan langit-langit (ق), lidah hampir pangkal dengan

${ }^{18}$ Dt. Tombak Alam, Ilmu Tajwid Populer 17 Kali Pandai, (Jakarta : Bumi Aksara, 1995), hlm. 23

${ }^{19}$ As'ad Humam, Cara Cepat Belajar Tajwid Praktis, (Yogyakarta : Tim Tadarus AMM, 2005), hlm. 55 
langit-langit (ك), lidah bagian ش ش ج ( tengah dengan langit-langit dan (ي), tepi lidah kanan atau kiri dengan memanjang dari pangkal sampai depan (ض), tepi lidah kanan dan kiri sampai ujung lidah dengan gusi atas (ل), ujung lidah dengan gusi atas (ن), ujung lidah dengan gusi atas dekat makhraj nun ( $)$, punggung kepala lidah dengan pangkal gigi seri atas ( ط د dan ت), ujung lidah dengan pangkal gigi seri yang atas ( ص dan j), dan ujung lidah dengan ujung dua buah gigi atas (ظ)

3) Asy-Syafatain (bibir) meliputi : Bibir bawah dengan ujung gigi atas (ف), bibir atas dan bawah dengan rapat (ب), dan bibir atas dan bawah dengan agak renggang sedikit (g)

4) Al-Jauf (rongga mulut) meliputi : semua huruf mad yaitu alif, ya' dan wawu

5) Al-Khoisyum (Pangkal hidung) meliputi : Nun sukun atau tanwin ketika di idgham bighunnahkan, di ikhfa;kan serta di iqlabkan dan mim sukun yang di idghamkan pada mim dan di ikhfa'kan pada ba'.

\section{c. Shifatul Huruf}

Setiap huruf memiliki sifat atau karakteristik masing-masing sehingga memudahkan untuk membedakan antara satu huruf dengan huruf lainnya. Sifat-sifat huruf tersebut adalah Jahr, Rokhowah, Syiddah, dan

\footnotetext{
${ }^{20}$ As'ad Humam, Cara cepat, hlm. 57

${ }^{21}$ Ahmad Munir dan Sudarsono, Ilmu Tajwid dan Seni Baca Al-Qur'an, (Jakarta : PT Rineka Cipta, 1994), hlm. 9
}

sebagainya. Selain memiliki sifat, huruf-huruf tersebut memiliki hukum bacaan diantara lain hukum bacaan nun mati, hukum bacaan mim mati, bacaan iamalah, bacaan naql dan lain sebagainya. ${ }^{20}$

d. Kelancaran/At-Tartil

Dalam Al-Qur'an surat Al Muzammil ayat 4 Allah berfirman yang artinya :

"...atau lebih dari (seperdua) itu, dan bacalah Al-Qur'an itu dengan perlahan-lahan..." (QS. $\quad \mathrm{Al}$ Muzammil : 04)

Berdasarkan firman Allah yang termaktub dalam Al-Qur'an surat AlMuzammil ayat 4 tersebut, Allah memerintahkan kepada hamba-Nya untuk membaca Al-Qur'an dengan tartil atau perlahan-lahan. Perintah tersebut dimaksudkan agar yang membaca Al-Qur'an mampu menghayati bacaan Al-Qur'an dan benar-benar memahami isinya. Bacaan Al-Qur'an yang perlahan dan menerapkan ilmu tajwid akan terdengar nyaman ditelinga pembaca dan pendengarnya.

Menurut Ali bin Abi Thalib ra, tartil adalah memperindah/memperbaiki bacaan Al-Qur'an serta mengerti dan menerapkan hukum ibtida' dan waqaf. ${ }^{21}$ Sedangkan menurut As'ad Humam dalam bukunya, tartil adalah memperindah bacaan-bacaan dalam Al-Qur'an dengan perlahan, teratur, jelas dan terang serta menerapkan illmu tajwid..$^{22}$

Dengan demikian bacaan Al-Qur'an yang baik adalah bacaan Al-Qur'an

${ }^{22}$ As'ad Humam, Cara Cepat Belajar Tajwid Praktis, (Yogyakarta : Balai Litbang LPTQ Nasional Tim Tadarus, AMM, 2005), hlm. 4 
yang dilakukan dengan tenang, perlahan, tidak terburu-buru dan benar sesuai aturan tajwid dan ilmu AlQur'an lainnya.

\section{Tata Cara/Adab Membaca Al-Qur'an}

Dalam islam, Al-Qur'an mengajarkan segala sesuatu lengkap dengan adab yang harus digunakan oleh seorang muslim. Seperti ketika membaca Al-Qur'an, ada adab-adab yang harus diperhatikan agar tidak melenceng dari aturan yang sudah ditetapkan sehingga membacanya dapat bernilai sebagai ibadah.

Adapun adab-adab bagi orang yang hendak membaca Al-Qur'an adalah ${ }^{23}$ :

1) Badan senantiasa suci dari hadast dan najis

2) Pakaian dan tempat membaca AlQur'an suci dari hadast dan najis

3) Saat membaca Al-Qur'an jangan sambil mengunyah makanan atau sejenisnya

4) Sebelum membaca Al-Qur'an hendaknya membaca ta'awudz, bismillah, dan ketika sudah selesai membaca bacalah Sadaqallahul adzim

5) Membaca Al-Qur' an dengan tenang, perlahan dan tidak tergesa-gesa (Tartil)

6) Bersikap tenang, menghadap kiblat, dan tidak disertai hati yang riya' dan sombong

7) Niat membaca Al-Qur'an hanya karena ingin mendapatkan ridlo Allah semata

8) Membaca Al-Qur'an dengan menghadap ke arah kiblat

${ }^{23}$ Hidayatullah Hasani dkk, Kaidah-kaidah Tajwid dalam membaca Al-Qur'an, (Yogyakarta : Lembaga Pendidikan Al-Qur'an Masjid Syuhada', 2007), hlm. 13
9) Ketika ada bacaan ayat sajadah, hendaknya melakukan sujud tiawah atau membaca tasbih

10) Berusaha memahmi isi dan kandungan setiap ayat

11) Mengagungkan dan mengesakan Allah ketika membaca wahyu ilahi, dengan demikian diharapkan terasa ni'mat dalam hati pembacanya

12) Senantiasa berusaha agar becaan tersebut selalu membekas dihati dan berusaha mengamalkan kandungan Al-Qur'an

\section{Faktor yang Mempengaruhi \\ Kemampuan Membaca Al-Qur'an}

Kemampuan membaca Al-Qur'an berkaitan dengan kondisi masing-masing individu. Ada beberapa orang yang belajar Al-Qur'an dengan istiqomah sampai akhirnya benar-benar lancar, ada yang sekedar belajar saja tanpa ada target untuk lancar, dan juga ada yang belajar Al-Qur'an karena paksaan atau tekanan dari lingkungan sekitar. Sehingga dapat disimpulkan bahwa tingkat kemampuan membaca Al-Qur'an setiap individu berbeda sesuai dengan faktor-faktor yang mempengaruhinya. Muhibbin Syah berpendapat bahwa faktor tersebut adalah faktor internal dan faktor eksternal. ${ }^{24}$

a. Faktor Internal

Faktor internal merupakan faktor dari dalam diri individu masingmasing. Faktor ini terdiri atas faktor fisiologis dan faktor psikologis.

1) Faktor Fisiologis

Adalah faktor yang berhubungan dengan keadaan jasmani atau fisik

${ }^{24}$ Muhibbin Syah, Psikologi Pendidikan dengan Pendekatan Baru, (Bandung : Remaja Rosdakarya, 1995), hlm. 138 
setiap individu. Kondisi fisik yang normal seperti pada umumnya menjadi faktor penentu keberhasilan individu dalam proses belajar. Misalnya, seseorang yang memiliki gangguan pada lidah tentu akan mempengaruhi tingkat kejelasan saat berbicara dan membaca terutama dalam membaca Al-Qur'an. Kondisi fisik yang sehat juga mempengaruhi tingkat kemampuan seorang anak, fisik yang lemah dan sering sakit sakitan juga akan berpengaruh pada proses pembelajaran seorang anak.

2) Faktor Psikologis

Faktor ini berhubungan dengan kondisi kejiwaan dan mental dalam diri seseorang yang dapat mendorong untuk lebih giat dalam belajar. Faktor psikologis meliputi : (1) Intelegensi, yaitu kemampuan untuk mempermudah melakukan penyesuaian secara tepat terhadap lingkungan sosial seseorang. ${ }^{25}$ Kecerdasan seseorang dapat dilihat dari beberapa cirinya yaitu cepat menangkap terhadap pelajaran, selalu ingin tahu sesuatu yang baru, dorongan terhadap sesuatu yang positif kuat, banyak ide dan kreatif. Tingkat kecerdasan seseorang juga menjadi faktor penentu tingkat kemampuan seseorang dalam membaca Al-Qur'an. (2) Minat, yaitu keingintahuan dan kecenderungan yang tinggi terhadap sesuatu. Minat memiliki pengaruh yang besar terhadap kemampuan seseorang memahami sesuatu seperti membaca AlQur'an. Minat yang tinggi akan menghasilkan kemampuan yang tinggi juga. Minat berhubungan dengan perasaan individu, ketika seseorang melakukan sesuatu dengan senang maka tingkat keberhasilan akan tinggi pula. (3) Motivasi, merupakan sesuatu yang mendorong seseorang untuk melakukan sesuatu. Motivasi dapat menentukan tingkat kemampuan seseorang dalam membaca AlQur'an. Motivasi belajar yang tepat dan usaha yang tekun akan membuahkan hasil yang baik.

b. Faktor Eksternal

Faktor eksternal merupakan faktor yang berasal dari luar individu. Faktor ini dapat dibedakan menjadi dua, yaitu faktor eksternal lingkungan sosial dan faktor eksternal non sosial.

1) Faktor Lingkungan Sosial

Lingkungan sosial berhubungan dengan keadaan sosial disekitarnya, lingkungan sosial meliputi keluarga, masyarakat disekitar, guru dan teman sepermainan. Segala sesuatu yang ada di sekitar siswa merupakan lingkungan sosialnya. Lingkungan sosial seorang siswa yang banyak memberikan pengaruh terhadap proses pembelajaran siswa adalah lingkungan sekolah, lingkungan

${ }^{25}$ Oemar Hamalik, Psikologi Belajar dan Mengajar, (Bandung : Sinar Baru Algesindo, 2000), hlm. 89 
keluarga serta lingkungan

masyarakat disekitarnya. Misalnya seorang siswa tumbuh diantara keluarga yang agamis maka dia akan tumbuh menjadi seorang siswa yang agamis, jika seorang siswa tumbuh di lingkungan keluarga yang tidak terlalu agamis dan kondisi sosial masyarakatnya juga banyak yang menganut agama yang berbeda, maka kemungkinan besar siswa tersebut juga tumbuh sebagai siswa yang tidak terlalu agamis dan tidak terlalu mengenal perbedaan antara agamanya dan agama yang dianut orang lain. Selain kondisi sosial keluarga dan masyarakat, latar belakang pendidikan juga mempengaruhi kemampuan siswa dalam membaca Al-Qur'an. Misal, siswa yang pernah mengenyam pendidikan AlQur'an di Madrasah akan berbeda hasilnya dengan siswa yang tidak pernah mengenyam pendidikan AlQur'an sebelumnya.

2) Faktor Lingkungan Non Sosial Faktor lingkungan non sosial meliputi akses pendukung bagi seorang individu. Seperti pada seorang siswa, maka lingkungan non sosialnya meliputi gedung rumah dan letaknya, gedung sekolah dan letaknya, cuaca dan waktu belajar yang digunakan oleh siswa. $^{26}$ Faktor tersebut dinilai

26 Muhibbin Syah, Psikologi Pendidikan dengan Pendekatan Baru, (Bandung : Remaja Rosdakarya, 1995), hlm. 138

${ }^{27}$ Kamus Besar Bahasa Indonesia, di akses pada Minggu, 26 Mei 2019 menjadi salah satu penentu kemampuan siswa dalam membaca Al-Qur'an. Seperti contoh, siswa tidak akan nyaman belajar di gedung sekolah yang kumuh, bocor di saat hujan dan banyak hal lainnya. Letak sekolah yang berada di tempat tidak semestinya (di tengah kuburan, misal) juga menentukan tingkat kenyamanan siswa ketika belajar.

\section{Konsep Internalisasi}

\section{Pengertian Internalisasi}

Menurut Kamus Besar Bahasa Indonesia internalisasi diartikan sebagai sebuah pendalaman, penghayatan, penguasaan secara mendalam yang dimulai dengan sebuah binaan, dampingan dan lain sebagainya. ${ }^{27}$ Menurut Johnson dalam bukunya, internalisasi merupakan proses yang mana orientasi nilai budaya dan harapan peran benar-benar disatukan dengan sistem kepribadian. ${ }^{28}$ Berdasarkan penjelasan diatas, dapat disimpulkan bahwa internalisasi adalah suatu penghayatan nilai atau norma sehingga menjadi suatu kesadaran dalam melakukan suatu sikap dan tindakan.

Selain itu menurut Kalidjernih, internalisasi adalah sebuah proses dimana individu belajar dan diterima menjadi bagian sekaligus mengikat diri dalam nilai-nilai dan norma-norma sosial dari perilaku sosial masyarakat. ${ }^{29}$ Individu tersebut kemudian secara tidak langsung mulai mengikuti

28 Johnson, Teori Sosiologi Klasik dan Modern, (Jakarta : PT Gramedia, 1986), hlm. 124

${ }^{29}$ Kalidjernih, Study Kewarganegaraan, Perspektif Sosiologikal dan Politikal, (Bandung : Widya Aksara, 2010), hlm. 71 
kebiasaan-kebiasaan apapun yang ada di lingkungan masyarakatnya. Dengan demikian, internalisasi merupakan suatu proses penanaman nilai-nilai dan norma-norma dalam diri individu.

\section{Pengertian Lingkungan Sosial}

Seperti yang sudah dijelaskan sebelumnya, lingkungan sosial merupakan salah satu faktor eksternal yang mempengaruhi tingkat kemampuan seorang anak dalam membaca Al-Qur'an. Lingkungan sosial berhubungan dengan keadaan sosial disekitarnya, lingkungan sosial meliputi keluarga, masyarakat disekitar, guru dan teman sepermainan. Segala sesuatu yang ada di sekitar siswa merupakan lingkungan sosialnya.

Lingkungan sosial seorang siswa yang banyak memberikan pengaruh terhadap proses pembelajaran siswa adalah lingkungan sekolah, lingkungan keluarga serta lingkungan masyarakat disekitarnya. Misalnya seorang siswa tumbuh diantara keluarga yang agamis maka dia akan tumbuh menjadi seorang siswa yang agamis, jika seorang siswa tumbuh di lingkungan keluarga yang tidak terlalu agamis dan kondisi sosial masyarakatnya juga banyak yang menganut agama yang berbeda, maka kemungkinan besar siswa tersebut juga tumbuh sebagai siswa yang tidak terlalu agamis dan tidak terlalu mengenal perbedaan antara agamanya dan agama yang dianut orang lain. Selain kondisi sosial keluarga dan masyarakat, latar belakang pendidikan juga mempengaruhi kemampuan siswa dalam membaca Al-Qur'an. Misal, siswa yang pernah mengenyam pendidikan Al-Qur'an di Madrasah akan berbeda hasilnya dengan siswa yang tidak pernah mengenyam pendidikan Al-Qur'an sebelumnya. Sebab, awal permulaan dalam pembelajaran juga menentukan bagaimana tingkat kemampuan siswa dalam membaca Al-Qur'an.

Secara tidak langsung, internalisasi lingkungan sosial yaitu seorang individu mengidentifikasi diri ditengah-tengah masyarakat sosial dimana individu tersebut terlibat di dalamnya. Selain itu, internalisasi lingkungan sosial dapat diartikan sebagai penanaman nilai-nilai sosial yang baik yang dilakukan oleh lingkungan sekitar sehingga berpengaruh terhadap karakter dan perilaku seorang individu.

\section{Internalisasi dalam Teori Konstruksi Sosial}

Kostruksi sosial adalah teori yang dibangun oleh Peter L. Berger yang menjelaskan tentang perilaku manusia dengan tiga proses, yaitu : Internalisasi, Eksternalisasi dan Obyektifikasi. ${ }^{30}$ Lebih jelasnya akan dijelaskan pada skema berikut :

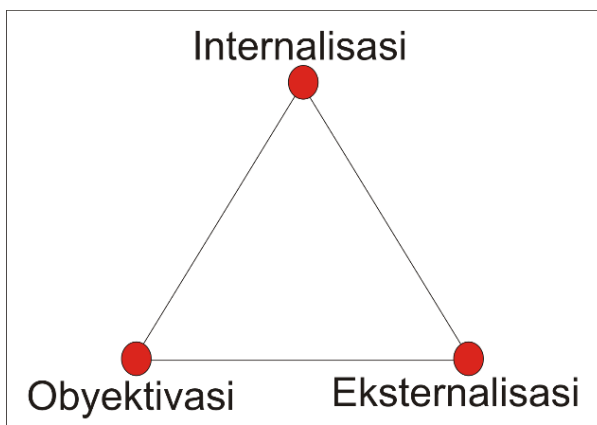

Gambar 1. Skema Teori Konstruksi Sosial Peter L. Berger

30 Peter L. Berger dan Thomas Luckman, Tafsir Sosial atas Kenyataan: Sebuah Risalah Tentang Sosiologi Pengetahuan, (Jakarta : LP3ES, 1990), hlm. 7 
Internalisasi yang dimaksud disini adalah meminjam teori konstruksi sosial dari Peter L. Berger yang secara ringkas akan dijelaskan berikut ini : Teori konstruksi sosial Peter L. Berger mengasumsikan bahwa realitas dan agensi (manusia) mempunyai hubungan timbal balik dengan skema eksternalisasi, obyektivasi dan internalisasi.

a. Eksternalisasi ialah penyesuaian diri dengan dunia sosio-kultural sebagai produk manusia "Society is a human product". Eksternalisasi dapat dinyatakan sebagai momen adaptasi diri.

b. Objektivasi ialah interaksi sosial dalam dunia intersubjektif yang dilembagakan atau mengalami institusionalisasi. "Society is an objective reality"

c. Internalisasi ialah individu mengidentifikasi diri di tengah lembaga-lembaga sosial atau organisasi sosial di mana individu tersebut menjadi anggotanya. "Man is a social product". ${ }^{31}$

\section{Proses Internalisasi}

Internalisasi terjadi sepanjang hidup yaitu sejak seseorang tersebut dilahirkan hingga akhir hayatnya. Sepanjang hidup seorang individu terus belajar mengolah rasa, hasrat dan nafsu yang akan membentuk kepribadiannya. Sejak lahir, setiap manusia sudah dibekali dengan bakat tertentu dalam dirinya. Namun, pengaktifan dan pengembangan nilai tersebut akan berubah-ubah sesuai

${ }^{31}$ Peter L. Berger dan Thomas Luckmann, Tafsir, hlm. 7

${ }^{32}$ Marmawi Rais, Internalisasi Nilai Integrasi Untuk Menciptakan Keharmonisan Hubungan Antar Etnik, dengan kondisi yang mempengaruhinya serta sesuai dengan keadaan sosial di lingkungannya.

Adanya proses internalisasi yang berkepanjangan akan membantu seseorang untuk menemukan dan mendefinisikan bagaimana jati diri sebenarnya melalui nilai-nilai yang sudah tercipta dan berkembang dalam bentuk serangkaian nilai-nilai dan norma. Hal ini senada dengan yang dikemukakan oleh Marmawi Rais, yaitu :

"Proses internalisasi lebih lazimnya akan cepat terwujud melalui peran aktif model (role-models). Seorang individu mendapatkan seseorang yang dapat dihormati dan dijadikan panutan sehingga ia dapat menerima serangkaian nilai dan norma yang ditunjukkan melalui keteladanan sikap dan perilaku. Proses ini dalam psikologi maupun sosiologi lazimnya dinamakan sebagai identifikasi. Sikap dan perilaku tersebut terbentuk melalui asimilasi yang subsadar dan nir-sadar"32

Berdasarkan pendapat diatas dapat disimpulkan bahwa proses internalisasi akan lebih mudah apabila ada karakter yang dijadikan sebagai panutan dan contoh. Seseorang akan menginternalisasikan sesuatu melalui keteladanan yang diperankan sehingga seorang individu dapat dengan cepat menyerap nilai-nilai dan norma-norma yang disisipkan di dalamnya. Pada hakikatnya, internalisasi merupakan proses penanaman sesuatu, sikap, keyakinan, pandangan yang akan

2012. Desertasi pada program pascasarjana PPU Bandung. Tidak di terbitkan, hlm. 10 di akses pada Minggu, 26 Mei 2019 
membentuk sikap dan perilaku seorang individu.

\section{Kemampuan Membaca Al-Qur'an Siswa- Siswi MAN 1 Malang}

Madrasah Aliyah Negeri 1 Malang merupakan lembaga pendidikan berbasis keagamaan dibawah naungan Departemen Keagamaan. Tuntutan masyarakat terhadap lembaga yang berbasis madrasah terangkum dalam bentuk mindset, bahwa siswa-siswi madrasah harus lebih mumpuni dalam menguasai pengetahuan agama dibandingkan dengan sekolah lain yang sederajat. ${ }^{33}$ Kenyataan ini juga di dukung oleh mata pelajaran yang sedikit berbeda antara madrasah dan sekolah. Jika pada sekolah mata pelajaran agama tergabung dalam satu mapel yang bernama Pendidikan Agama Islam (PAI), maka di madrasah mata pelajaran agama dipelajari secara detail dalam bentuk mapel Fiqh, Aqidah Akhlaq, Al-Qur'an Hadist, Sejarah Kebudayaan Islam dan masih banyak lainnya.

Sehubungan dengan mata pelajaran keagamaan yang dipelajari secara detail dan komplit, tidak menutup kemungkinan bahwa siswa-siswi madrasah terbiasa dengan kajian dan literatur agama yang berbahasa Arab serta menggunakan hadist dan ayat-ayat Al-Qur'an sebagai sumber rujukan. Secara umum, siswa-siswi madrasah akan dipandang sebagai siswasiswi yang lebih mumpuni dalam memahami agama secara mendalam dibandingkan anak seusianya yang mengenyam pendidikan di sekolah. Pernyataan tersebut di dasari bahwa siswa/i madrasah lebih sering belajar agama dibandingkan dengan siswa/i di sekolah.

Senada dengan pernyataan diatas, siswa/i madrasah dipandang lebih fashih

\footnotetext{
${ }^{33}$ Hasil Wawancara kepada Masyarakat Sekitar di Putat Lor Pada Tanggal 25 Mei 2019
}

dalam melafalkan bahasa yang menjadi simbol agama islam yakni Bahasa Arab, khususnya dalam membaca Al-Qur'an. Kemampuan seseorang dalam membaca AlQur'an tidak semata-mata diwajibkan bagi siswa/i madrasah, akan tetapi merupakan kewajiban bagi seluruh umat muslim untuk membaca Al-Qur'an dengan baik. Sebab, selain menjadi pedoman hidup bagi manusia, membaca Al-Qur'an akan menjadi nilai ibadah bagi pembacanya.

Berbanding terbalik dengan tuntutan dan pernyataan masyarakat pada umumnya, di MAN 1 Malang terdapat siswa-siswi yang tidak dapat membaca AlQur'an dengan baik dan benar sesuai dengan indikator yang sudah di tetapkan. Fenomena ini diketahui ketika sekolah membuat kebijakan untuk melakukan tes membaca Al-Qur'an bagi siswa-siswi baru setiap tahunnya. Tes membaca Al-Qur'an diadakan guna untuk mewujudkan visi misi Madrasah yakni membentuk siswa/i yang religius dan mengamalkan ajaran agama dalam kehidupan sehari-hari. Salah satu bentuk realisasi dari visi misi tersebut adalah adanya program mengaji selama 15 menit sebelum memulai pelajaran pertama. Pada tahun ajaran 2018/2019, MAN 1 Malang membentuk struktur kepanitiaan tes membaca Al-Qur'an bagi seluruh siswasiswi di MAN 1 Malang secara keseluruhan. Keputusan tersebut berdasarkan rapat besar antar waka dan kepala bagian agar dapat menyaring dan mengetahui sejauh mana tingkat kemampuan siswa/i MAN 1 Malang dalam membaca Al-Qur'an. ${ }^{34}$

Tes membaca Al-Qur'an yang dilakukan pada semua kelas bertujuan agar siswa/i kelas XI dan XII yang masih belum bisa membaca Al-Qur'an dapat mengikuti program bimbingan yang akan diadakan.

\footnotetext{
${ }^{34}$ Hasil wawancara dengan Bpk. Pa'is M.A. selaku Waka Kesiswaan pada tanggal 24 Mei 2019 di MAN 1 Malang
} 
Sehingga mereka memiliki ruang tambahan untuk belajar membaca Al-Qur'an. ${ }^{35}$

Berdasarkan hasil rapat panitia inti yang berjumlah 4 orang, standar kelulusan dalam pelaksanaan tes membaca Al-Qur'an dibagi menjadi 3 aspek yaitu : penerapan tajwid, kefashihan dalam bacaan (Makharijul Huruf dan Shifatul Huruf tepat) dan kelancaran saat membaca. Standar penilaian tersebut tidak memiliki aturan yang baku dan termuat dalam dokumen resmi. Artinya, seluruh penguji bebas menafsirkan sejauh mana siswa/i dikatakan sudah memenuhi kriteria kelulusan dalam tes membaca AlQur'an.

Tes membaca Al-Qur'an dilakukan secara serentak pada pertengahan bulan Agustus. Metode yang digunakan diseragamkan yakni siswa/i maju secara bergantian dan membaca sekitar 5 sampai 10 ayat yang ditentukan oleh penguji. Kemudian siswa/i diklasifikasi menjadi tiga bagian dengan kode A, B dan C. A berarti siswa/i mampu menerapkan tajwid dalam bacaannya, fashih dan lancar. Sehingga dinyatakan lulus dengan nilai sempurna. Kategori B berarti siswa/i membaca dengan lancar akan tetapi tidak menerapkan ilmu tajwid dan bacaannya tidak fashih. Sedangkan C artinya siswa/i membaca AlQur'an dengan tidak menerapkan ketiga aspek yang ditentukan. Siswa/i yang dekelompokkan di B dan C akan menjalani program khusus yang ditetapkan oleh sekolah.

Terdapat 49 siswa siswi yang dikategorikan sebagai siswa/i yang belum mampu membaca Al-Qur'an dengan fashih, lancar dan menerapkan ilmu tajwid. Angka 49 dari 952 siswa/i jika di prosentasekan menjadi 5.14\%. Meskipun angka tersebut

${ }^{35}$ Hasil wawancara dengan Bpk. Mulyono, S.Pd.I selaku koordinator pembinaan Al-Qur'an pada tanggal 29 Mei 2019 di MAN 1 Malang terbilang sedikit, tapi pihak madrasah tidak menginginkan anak didik yang keluar dari MAN 1 Malang tidak dapat membaca AlQur'an. Pernyataan ini disampaikan oleh Pak Mulyono selaku ketua koordinator tes membaca Al-Qur'an.

Pernyataan beliau mengindikasikan bahwa standar penilaian yang diterapkan dalam tes tidak memiliki aturan yang baku dan tercatat dalam dokumen resmi. Pasalnya standar penilaian tersebut ditentukan saat rapat oleh panitia inti yang berjumlah 4 orang. Seperti yang sudah dijelaskan sebelumnya, panitia memberikan kebebasan bagi penguji untuk menafsirkan 3 aspek kelulusan yang ditentukan oleh panitia. Hanya metode tes yang diseragamkan yakni menggunakan metode sema'an beberapa ayat Al-Qur'an yang ditentukan masing-masing penguji. Panitia menyadari bahwa disinilah letak kelemahan penyaringan kemampuan siswa/i dalam membaca Al-Qur'an, sebab antara satu penguji dengan penguji lainnya memiliki persepsi yang berbeda-beda. ${ }^{36}$ Selain itu, adanya siswa/i yang tidak dapat membaca Al-Qur'an menjadi beban moral bagi beliau-beliau, khususnya dirasakan oleh beliau-beliau yang mendapatkan amanah untuk menyaring dan menguji bacaan Al-Qur'an peserta didik.

\section{Internalisasi Lingkungan Sosial Siswa- Siswi MAN 1 Malang}

Konstruksi sosial merupakan sebuah teori yang dibangun oleh Peter L. Berger yang menjelaskan perilaku manusia dengan tiga proses yaitu internalisasi, eksternalisasi dan obyektifikasi. ${ }^{37}$ Yang akan dijelaskan disini adalah proses internalisasi lingkungan sosial siswa/i MAN 1 Malang yang tidak dapat membaca Al-Qur'an

36 Hasil wawancara dengan Ibu Ina Husnatul Amalia, M.Pd.I selaku sekretaris pembinaan AlQur'an pada tanggal 29 Mei 2019 di MAN 1 Malang

${ }^{37}$ Peter L. Berger dan Thomas Luckman, Tafsir, 7 
sesuai dengan aspek penilaian yang ditetapkan. Internalisasi adalah individu mengidentifikasi diri ditengah lembagalembaga sosial atau organisasi sosial dimana individu tersebut terlibat di dalamnya. Sedangkan lingkungan sosial berhubungan dengan keadaan sosial disekitarnya, lingkungan sosial meliputi keluarga, masyarakat disekitar, guru dan teman sepermainan. Segala sesuatu yang ada di sekitar siswa merupakan lingkungan sosialnya.

Secara tidak langsung, kemampuan membaca Al-Qur'an siswa/i MAN 1 Malang berkaitan dengan proses internalisasi. Internalisasi adalah seorang individu mengidentifikasi diri ditengah-tengah masyarakat sosial dimana individu tersebut terlibat di dalamnya. Selain itu, internalisasi dapat diartikan sebagai penanaman nilainilai sosial yang yang dilakukan oleh lingkungan sekitar sehingga berpengaruh terhadap karakter dan perilaku seorang individu. Internalisasi lingkungan sosial secara tidak langsung akan membentuk nilai-nilai dalam diri manusia.

Tokoh agama merupakan salah satu individu yang dapat melakukan internalisasi melalui lembaga sosialnya seperti KUA, pesantren, TPQ dan lembaga pendidikan non formal lainnya. Dari 6 sampel observasi, 3 wilayah tempat tinggal/i memiliki sekurang-kurangnya 10 warga yang lulusan pesantren. Selain warganya, $50 \%$ tokoh agama yang ada merupakan lulusan pesantren. Sehingga sedikit banyak sikap dan kebijakan yang diabil berdasarkan dengan backgroundnya sebagai lulusan pesantren. Tentu yang demikian akan berpengaruh terhadap proses internalisasi yang dilakukan.

Masyarakat sekitar dari 6 sampel observasi merupakan masyarakat yang aktif dalam melakukan kegiatan keagamaan. Terbukti dari seluruh sampel observasi memiliki rutinan kegiatan keagamaan di desanya. Kegiatan keagamaan tersebut berupa tahlilan, pembacaan maulid diba'iyah, manaqiban, dan tasyakuran setiap malam jum'at. Meskipun demikian, kegiatan tersebut tidak pernah diikuti oleh siswa/i. Sebab sudah menjadi tradisi masyarakat sekitar bahwa kegiatan tersebut diperuntukkan bagi ibu-ibu dan bapak-bapak.

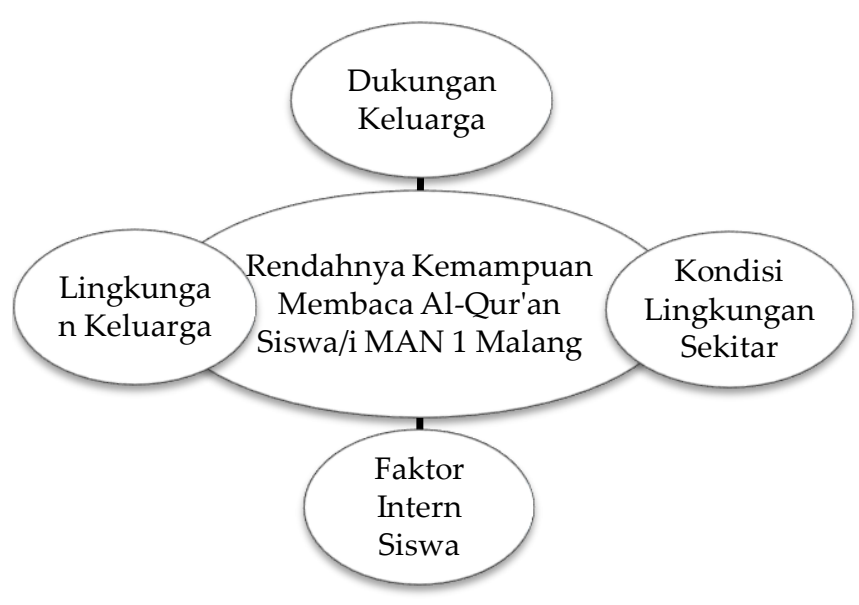

Gambar 2. Faktor Lingkungan Sosial dalam Kemampuan Membaca Al-Qur'an

Skema diatas menunjukan rendahnya kemampuan membaca Al-Qur'an siswa/i MAN 1 Malang disebabkan oleh faktorfaktor berikut :

\section{Dukungan Keluarga}

Berdasarkan hasil observasi dan wawancara kepada 6 responden berikut keluarganya, terdapat 4 orang tua siswa/i yang tidak terlalu mendukung terhadap pendidikan agama. Orang tua tidak memiliki target pencapaian pemahaman agama bagi anak, sehingga mengakibatkan adanya batasan umur dalam belajar ilmu agama. Secara otomatis siswa/i seusia SMP berhenti belajar ilmu agama di lembaga pendidikan islam seperti Taman Pendidikan Al-Qur'an. Kendati demikian, orang tua tidak merasa terbebani dengan alasan putra putrinya 
sudah mengenyam pendidikan di sekolah. ${ }^{38}$

Adanya pernyataan dari orang tua yang dikuatkan dengan argumen siswa sebagai anak, dapat disimpulkna bahwa dukungan keluarga merupakan faktor penentu penguasaan membaca Al-Qur'an bagi siswa/i. Pasalnya keluarga merupakan pendidikan pertama yang di dapatkan oleh anak. Apapun yang terjadi pada lingkungan keluarganya, maka seorang anak akan mudah menyerap dan menjadikannya sebagai teladan. Terlebih sebuah dukungan dan arahan sosok keluarga dalam diri seorang anak.

\section{Kondisi Lingkungan Sekitar}

Siswa/i yang tinggal dalam lingkungan pesantren dan tidak akan memiliki pola sikap yang berbeda. Sebab pola lingkungan masyarakat juga menjadi salah satu penentu terbentuknya karakter individu. Berdasarkan hasil observasi dan wawancara, di wilayah 4 responden kami yaitu Donomulyo, Gunung Kawi, Sidomulyo dan Bululawang jika ada anak usia $6-17$ tahun yang tidak mengenyam pendidikan agama di lembaga non formal (TPQ, Pesantren) maka dianggap tabu. Berbeda dengan wilayah 2 responden kami yaitu Donomulyo dan Wagir, masyarakat disana memiliki pola berfikir bahwa belajar agama di sekolah sudah mewakili. Menurutnya, taman Pendidikan Al-Qur'an yang ada di kampung-kampung hanya cocok bagi anak usia Sekolah Dasar saja.

Tiga dari enam rumah yang di observasi jauh dari pesantren dan TPQ berjarak lebih dari 2 KM. Hitungan 2

${ }^{38}$ Hasil wawancara dengan Ibu Winarsih selaku orang tua siswi pembinaan Al-Qur'an pada tanggal 12 Juni 2019
KM jika ditempuh dengan berjalan kaki termasuk kategori jarak yang jauh. Setelah di wawancara, responden menyatakan bahwa letak lembaga pendidikan non formal yang jauh dari rumah menjadi alasan untuk tidak belajar di lembaga tersebut. Pada akhirnya mereka belajar pendidikan agama ala kadarnya dengan salah satu anggota keluarga, atau imam sholat di musholla terdekat. Dari seluruh sampel yang di observasi, tempat tinggalnya tidak jauh untuk mendapatkan akses musholla. Setiap dusun sekurangkurangnya memiliki tiga musholla.

Seluruh wilayah 6 responden kami memiliki kegiataan keagamaan seperti rutinan pembacaan tahlil, maulid diba'iyah, tadarus Al-Qur'an ketika bulan Romadlon dan istighotsah. Sebagai warga mereka mengikuti semua rutinan tersebut. Akan tetapi mereka memiliki pola pemahaman bahwa kegiataan keagamaan tersebut diperuntukkan untuk ibu-ibu dan bapak-bapak saja. Tidak ada inisiatif untuk merangkul dan membiasakan anak-anak untuk mengikutinya. ${ }^{39}$

Meskipun terdapat $>10$ lulusan pesantren di 3 wilayah observasi, tetap tidak dapat menghambat pola pemahaman yang berkembang di masyarakatnya. Pasalnya, angka lulusan pesantren yang berkisar antara 10 - 20 tidak lebih besar dari jumlah keseluruhan warga dusun yang latar belakang pendidikannya rendah dan masih menerapkan kepercayaan nenek moyangnya dalam kehidupan seharihari. Contoh : Warga Sumberoto Donomulyo percaya jika Kamis malam Jum'at leluhurnya akan pulang kerumah, sehingga mereka

39 Hasil wawancara dengan Bpk. Faqih selaku salah satu warga lulusan pesantren di Sumberoto pada tanggal 12 Juni 2019 
menyiapkan bunga kenanga, nasi, dan kopi di meja. Keesokan harinya sebagian dari mereka akan mencicipi rasa dari makanan tersebut, jika makanan tersebut rasanya hambar maka artinya leluhur mereka sudah memakan hidangan tersebut. ${ }^{40}$

Lima dari enam wilayah yang di observasi memiliki $50 \%$ tokoh agama lulusan pesantren. Setelah kami wawancara beliau menyatakan bahwa tokoh agama masih belum mampu untuk mendominasi dirinya ditengah masyarakat luas. Sehingga yang terjadi adalah mengikuti alur pemikiran yang sudah berkembang di masyarakat dan bersikap apatis terhadap pendidikan agama. Tokoh agama di masyarakat seperti mudin, kyai kampung dan penceramah memiliki andil yang sangat besar demi terciptanya masyarakat yang menjalani kehidupan sesuai dengan syariat agama. Rupanya tokoh agama di sekitar tempat tinggal siswa/i yang tidak dapat membaca AlQur'an memiliki konsep yang berbeda. Tokoh agama yang ada hanya fokus dengan dengan job pekerjaan yang tertulis (Misal : Mudin tugasnya menalqin jenazah, kyai kampung dan penceramah tugasnya berceramah). Tidak ada perhatian khusus kepada perkembangan lembaga pendidikan agama seperti TPQ dan tempat belajar agama lainnya. Serta tidak ada dorongan kepada masyarakat khususnya remaja untuk terus memperdalam ilmu agama. ${ }^{41}$

Selain tokoh agama, guru TPQ merupakan bagian dari lingkungan masyarakat. Seperti yang sudah

\footnotetext{
${ }^{40}$ Wawancara dengan Bapak Bagyo selaku Tokoh Agama di Gunung Kawi pada tanggal 14 Juni 2019

${ }^{41}$ Hasil wawancara dengan Bpk. Bagyo selaku tokoh agama di Gunung Kawi pada tanggal 14 Juni 2019
}

dijelaskan sebelumnya bahwa pola pikir masyarakat di sekitar tempat tinggal siswa/i yang tidak bisa membaca Al-Qur'an adalah pendidikan agama diluar sekolah tidak wajib dipelajari oleh anak seusia SMP keatas. Pola pikir demikian sudah tertanam sejak lama, sehingga tidak menjadi masalah bagi guru TPQ jika usia remaja sudah tidak belajar agama terutama membaca Al-Qur'an. Patokannya adalah ketika sudah lulus SD maka TPQ Pun ikut lulus, meskipun belum mencapai target dan belum mampu menguasai kemampuan dasar seperti membaca Al-Qur'an. ${ }^{42}$

\section{Lingkungan Keluarga}

Dari 6 keluarga yang di observasi, lima diantaranya memiliki standar pendidikan agama yang rendah. Hal ini dibuktikan dengan riwayat pendidikannya yang tamatan Sekolah Dasar dan berhenti saat Sekolah Dasar. Lingkungan keluarganya jauh dari kata religius sebab memang tidak ada pembiasaan keagamaan dalam kehidupan sehari-hari. Pembiasaan tersebut dapat berupa sholat jama'ah, sholat secara tepat waktu, terbiasa membaca Al-Qur'an, mengadakan kegiatan keagamaan dan lain sebagainya. Tidak adanya pembiasaan keagamaan dalam kehidupan seharihari salah satunya disebabkan karena tingkat pengetahuan ilmu agama yang rendah.

\section{Faktor Intern Siswa}

Selain lingkungan sosial, faktor dalam diri siswa/i juga menjadi penentu penguasaan dalam membaca Al-Qur'an. Dari 10 responden kami, 4

${ }^{42}$ Hasil Wawancara dengan Ibu Zainab selaku guru TPQ di Donomulyo pedalaman pada tanggal 12 Juni 2019 
siswa/i mengatakan bahwa saat ini (sesudah remaja) tidak memiliki kecenderungan untuk bisa membaca Al-Qur'an. Mereka menutup diri dari kenyataan yang ada bahwa mereka tidak bisa membaca Al-Qur'an dengan baik. Alasannya karena bagi mereka dapat membaca Al-Qur'an dengan baik bukan sebuah tuntutan dalam lingkungan sosialnya.

Mereka menyatakan bahwa keinginan dapat membaca Al-Qur'an ada, akan tetapi minat untuk belajar membaca tidak ada. Kosongnya minat disebabkan oleh faktor minimnya dukungan keluarga dan masyarakat sekitar. Sehingga mereka beranggapan bahwa membaca Al-Qur'an bukan sebuah keharusan. Menurutnya, dapat membaca Al-Qur'an meskipun tidak lancar tidak fashih, dan tidak menerapkan ilmu tajwid sudah cukup.

Upaya Sekolah dalam Meningkatkan Kemampuan Membaca Al-Qur'an SiswaSiswi MAN 1 Malang dalam Perspektif Sosiologi Pengetahuan

Sosiologi pengetahuan merupakan upaya untuk menjadikan pengetahuan sebagai objek perhatian dengan cara menerapkan perspektif sosiologi. ${ }^{43}$ Dengan demikian dapat dikatakan bahwa sosiologi pengetahuan merupakan suatu cabang dari ilmu sosiologi. Dalam ilmu sosiologi dipelajari bagaimana hubungan antara pengetahuan dan lingkungan sosial, yaitu bagaimana suatu pengetahuan diproduksi, didistribusi di tengah masyarakat melalui relasi sosial.

Indikator dalam sosiologi pengetahuan terbagi menjadi 5, yaitu : realitas subjektif, eksternalisasi, objektivikasi, internalisasi dan realitas objektif. Menurut Berger

\footnotetext{
${ }^{43}$ Peter L. Berger dan Thomas Luckman, Tafsir, 7
}

masyarakat merupakan realitas subkjektif sekaligus realitas objektif. Sebagai realitas subjektif, individu merupakan bagian dari masyarakat dan tidak dapat dipisahkan. Sedangkan sebagai realitas objektif, masyarakat ada diluar diri manusia dan sedang berhadapan dengannya. Indikator dari realitas subjektif memiliki tiga ciri dialektika yaitu eksternalisasi yang merupakan penyesuaian diri dengan sosio kultural, objektivikasi yaitu adanya interksi dunia intersubjektif yang dikembangkan atau mengalami institusionalisasi dan internalisasi yaitu individu mengidentifikasikan dirinya melalui lembaga sosial. Semua hal tersebut mengasilkan realitas objektif yang berupa fakta sosial dan berada di luar diri manusia. ${ }^{44}$

Pemikiran Peter L. Berger dan Luckmann dalam sosiologi pengetahuan selalu memahami dunia kehidupan (life world) dalam proses dialektik antara individu (the self) serta dunia sosio-kultural. Proses dialektik tersebut mencakup tiga momen simultan yang akan dijelaskan melalui skema berikut :

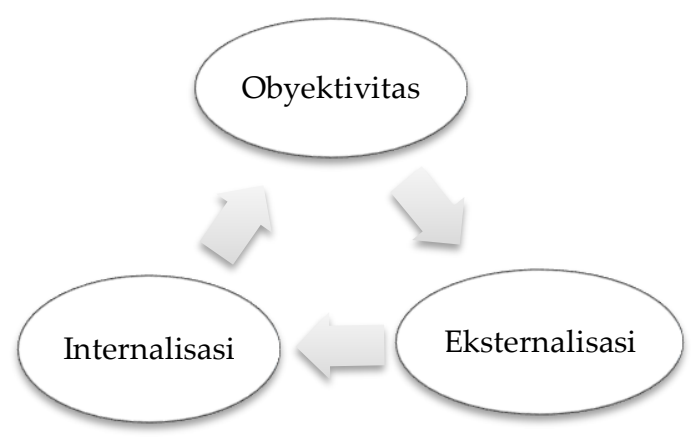

Gambar 2. Dialektika Konstruksi Sosial Peter L. Berger

Teori konstruksi sosial menyatakan bahwa manusia yang tinggal dalam konteks sosial tertentu melakukan serangkaian proses interaksi secara simultan dengan lingkungan sosialnya. Masyarakat hidup dalam realitas objektif yang dikonstruksi

\footnotetext{
${ }^{44}$ Peter L. Berger dan Thomas Luckman, Tafsir, 7
} 
melalui momen objektivikasi dan eksternalisasi, sedangkan dimensi subjektif dibentuk melalui momen internalisasi. Momen objektivikasi, internalisasi dan eksternalisasi akan terus berproses secara dialektik dalam masyarakat. Dengan begitu, realitas sosial merupakan hasil dari sebuah konstruksi sosial yang dibentuk oleh manusia itu sendiri. Dalam konteks penelitian ini, upaya yang dilakukan oleh MAN 1 Malang akan dilihat melalui perspektif sosiologi pengetahuan.

MAN 1 Malang saling berinteraksi dengan lingkungan sosial disekitarnya sehingga membentuk paradigma sosial yang mempengaruhi kebijakannya. Hasil dari interaksi tersebut kemudia menghasilkan suatu pembacaan bahwa MAN 1 Malang berdiri ditengah-tengah lingkungan pesantren. Stake holder MAN 1 Malang termasuk yang mewakafkan tanah, adalah bagian terpenting dari pesantren yang ada di Kec. Gondanglegi. Sehingga pola kebijakan MAN 1 Malang sebagai lembaga pendidikan formal yang berdiri dibawah naungan Departemen Keagamaan cenderung agamis. Tuntutan yang ada di masyarakat sebagai sekolah berbasis Madrasah adalah mampu membentuk siswa/i yang religius dan menganut ajaran agama dengan baik. Selain stake holder, hingga saat ini mayoritas pengajar di MAN 1 Malang adalah lulusan pesantren, kenyataan tersebut tentu mempengaruhi kebijakan dan program yang ada di MAN 1 Malang.

Indikator kedua dalam teori konstruksi sosial yang digagas oleh Peter L. Berger adalah internalisasi. Internalisasi adalah individu mengidentifikasi diri di tengah lembaga-lembaga sosial atau organisasi sosial dimana individu tersebut berada di

\footnotetext{
${ }^{45}$ Peter L. Berger dan Thomas Luckman, Tafsir, 7

46 Hasil wawancara dengan Bpk. Agung Sri Mulyono, S.Pd. selaku Waka Kurikulum pada tanggal 18 Juni 2019 di MAN 1 Malang
}

dalamnya. Selain itu, internalisasi juga dapat diartikan sebagai penanaman nilainilai dalam diri individu sehingga dianut dan dijadikan sebagai teladan. ${ }^{45}$ Adanya paradigma yang dihasilkan dari interaksi sosial tercermin dari visi misi yang ditetapkan oleh MAN 1 Malang saat rapat besar dan disahkan dalam dokumen resmi berupa Surat Keputusan (SK).

Visi misi MAN 1 Malang antara lain membentuk siswa/i yang religius dan menerapkan ajaran agama dalam kehidupan sehari-hari. Visi misi tersebut lahir berdasarkan paradigma integrasiinterkoneksi, yakni menghubungkan ilmu agama dengan kenyataan sosial yang terjadi. Kenyataan sosial yang terjadi adalah adanya tuntutan dari masyarakat untuk membentuk siswa/i yang menjalankan syari'at agama dengan baik sebab MAN 1 merupakan lembaga pendidikan formal yang dibangun oleh orang-orang pesantren dan ada ditengah-tengah lingkungan pesantren. Tuntutan tersebut berbanding terbalik dengan salah visi misi Madrasah yaitu menciptakan lingkungan religius di MAN 1 Malang dan membiasakan kegiatan keagamaan dalam kehidupan sehari-hari. Visi tersebut digagaas saat rapat besar oleh seluruh pimpinan, guru dan staff MAN 1 Malang pada awal tahun ajaran 2014/2015.46

Sejalan dengan visi misi yang dibentuk, maka program yang dijalankan guna mewujudkan visi dan misi MAN 1 Malang adalah Habitualisasi atau pembiasaan. Siswa/i MAN 1 dibiasakan untuk menerapkan ajaran agama dalam kehidupan sehari-hari dimulai dari lingkungan sekolah. Program tersebut terealisasi dalam bentuk ${ }^{47}$ :

\footnotetext{
${ }^{47}$ Hasil wawancara dengan Bpk. Mulyono, S.Pd.I selaku koordinator pembinaan Al-Qur'an pada tanggal 29 Mei 2019 di MAN 1 Malang
} 
162 | Mashdar : Jurnal Studi al-Quran dan Hadis, Vol.2 No.2 2020 (143-168)

1. Mengaji selama 15 menit sebelum memulai jam pertama

Siswa/i MAN 1 masuk kelas pada jam 07.00 kemudian mereka membaca AlQur'an selama 15 menit. Pembacaan ayat Al-Qur'an dimulai dari Juz 1 sampai selesai secara terus menerus. Siswa/i membaca Al-Qur'an dengan cara bersama-sama dipandu oleh dua orang petugas (bergantian setiap kelas) dari microfon pusat dan disalurkan dari sound yang dipasang disetiap kelas. Setelah 15 menit, dilanjutkan dengan membaca Asmaul Husna dan do'a mau belajar. Kemudian jam pelajaran pertama akan dimulai.

2. Sholat berjama'ah

Setiap hari siswa/i MAN diwajibkan untuk sholat Dzuhur dan Asyar berjama'ah di aula terbuka MAN 1 Malang. Bagi perempuan yang berhalangan ditempatkan di serambi musholla Nur Hamid dan akan mendapatkan bimbingan keputrian dari guru yang bertugas. Sholat berjama'ah juga diharuskan bagi pimpinan, guru dan seluruh staff MAN 1 Malang.

3. Sholat Dhuha berjamaah

Siswa/i MAN 1 sudah harus berada dilingkungan sekolah pada jam 06.45 WIB. Selanjutnya siswa/i diarahkan ke aula terbuka MAN 1 Malang untuk melaksanakan sholat dluha berjama'ah. Siswi yang berhalangan menuju musholla dan mendapatkan kegiatan berupa hafalan 15 mufrodat. Pemandu hafalah adalah guru piket yang sedang bertugas. Proses hafalan tidak dilakukan secara detail per individu, akan tetapi secara keseluruhan.

4. Mengisi Kultum

Ketika sholat jama'ah dzuhur dan asyar dilaksanakan, siswi yang berhalangan menuju musholla dan mendapatkan kultum. Pengisi kultum adalah teman-teman mereka sendiri yang dijadwal secara bergantian sesuai urutan kelas. Kultum disampaikan menggunakan 3 bahasa, yaitu Indonesia, Arab dan Bahasa Inggris. Setelah kultum selesai disampaikan, siswa/i mendapatkan kesempatan untuk bertanya. Kemudian ditutup dengan absen kehadiran.

5. Maulid diba'iyah bagi siswi yang berhalangan sholat

Khusus pada hari Jum'at, siswa melaksanakan sholat Jum'at di masjid Ar-Rohman Putat Lor. Sedangkan yang perempuan berjama'ah di musholla MAN bersama para guru. Bagi siswi yang berhalangan, mereka berkumpul di aula terbuka MAN dan melaksanakan kegiatan berupa pembacaaan maulid diba'iyah secara singkat. Pemandu maulid adalah perwakilan setiap kelas secara bergantian.

Program diatas merupakan bentuk institusionalisasi yakni proses membangun sebuah kesadaran menjadi sebuah tindakan. Karena visi misinya membentuk siswa/i yang religius dan membiasakan kegiatan kegamaan dalam kehidupan sehari-hari, maka program yang diadakan di MAN 1 Malang adalah Habitualisasi atau pembiasaan melaksanakan ajaran-ajaran agama. Pada program pertama tujuannya 
adalah membiasakan siswa/i agar gemar membaca Al-Qur'an. Hambatan pada program tersebut adalah adanya siswa/i yang tidak dapat membaca Al-Qur'an dan tidak memiliki minat untuk belajar membaca Al-Qur'an. ${ }^{48}$

Program pembiasaan membaca AlQur'an sebelum memulai pelajaran pertama digagas oleh Bagian Keagamaan dan anggotanya kemudian di sah kan pada saat rapat besar dan evaluasi seluruh pengajar dan staff MAN 1 Malang pada akhir tahun ajaran 2017/2018 (3 tahun yang lalu) ${ }^{49}$. Program pembiasaan ini dibentuk karena membaca Al-Qur'an merupakan sebuah keharusan bagi seorang muslim. Al-Qur'an merupakan pedoman dalam hidup manusia, bernilai ibadah bagi pembacanya serta Al-Qur'an akan datang sebagai pemberi syafa'at (pada hari kiamat) bagi yang istiqomah membaca, sesuai dengan hadist Rasulullah SAW yang artinya :

"Bacalah Al-Qur'an, karena ia akan datang sebagai pemberi syafa'at bagi pembacanya di hari kiamat nanti" (HR. Muslim)

Indikator ketiga dalam teori konstruksi sosial adalah eksternalisasi. Eksternalisasi disini merujuk kepada upaya yang dilakukan oleh sekolah dalam mengatasi fenomena yang ada. Menghadapi kenyataan bahwa $5.14 \%$ siswa/i MAN belum mampu membaca Al-Qur'an dengan baik, tentu madrasah memiliki upaya untuk menanganinya. Sebelum melangkah pada upaya penanganan siswa/i yang tidak mampu membaca Al-Qur'an, tentu pihak madrasah sedikit banyak harus mengetahui penyebab siswa/i tersebut tidak mampu membaca Al-Qur'an. Sebab penanganan atau pemberian solusi akan tepat jika diberikan sesuai dengan kondisi dan penyebab permasalah tersebut terjadi.

${ }^{48}$ Hasil wawancara dengan Bpk. Pa'is M.A. selaku Waka Kesiswaan pada tanggal 24 Mei 2019 di MAN 1 Malang
MAN 1 Malang memiliki fasilitas BK (Bimbingan Konseling) yang baik, hal tersebut dibuktikan dengan banyaknya siswa/i yang memilih untuk curhat dan meluapkan segala permasalahan yang dirasakan kepada guru BK. Siswa/i MAN 1 Malang merasakan bahwa guru BK bukan hanya sekedar guru, akan tetapi seseorang yang bisa menjadi sosok orang tua, teman, dan kakak sesuai dengan kondisi yang dibutuhkan. Banyak siswa/i yang menceritakan permasalahanya kepada guru $\mathrm{BK}$, mulai dari persoalannya dengan orang tua, temannya, teman lawan jenisnya dan lingkungan sekitarnya.

Bimbingan Konseling di MAN 1 Malang memiliki 4 guru yang ahli dalam bidangnya, yaitu Ibu Kustiani, Ibu Dwi, Ibu Maretha dan Bapak Sun'an. Biasanya siswa/i akan memilih dari 4 orang guru tersebut untuk dijadikan sebagai tempat meluapkan segala yang sedang dirasakan. Berdasarkan hasil observasi yang dilakukan peneliti kepada para konsultan BK, mereka menyatakan bahwa setiap siswa/i memiliki alasan masing-masing untuk kemudian menjatuhkan pilihan kepada siapa ia akan bercerita. Kebanyakan siswa/i memilih berdasarkan permasalahan apa yang sedang mereka hadapi.

Layanan konsultasi kepada guru Bimbingan Konseling (BK) sangat dimanfaatkan dengan baik oleh siswa/i MAN 1 Malang, hal ini terbukti dengan banyaknya siswa/i yang mengunjungi ruang BK ketika jam istirahat, jam kosong, jam pulang bahkan ketika sekolah sedang tidak efektif. Guru BK rata-rata hafal dengan nama dan raut wajah siswa/i MAN 1 Malang, hal ini disebabkan oleh seringnya mereka membagi waktu dengan siswa/i untuk layanan konseling. Layanan konseling di konsep untuk menghindari

\footnotetext{
${ }^{49}$ Hasil wawancara dengan Bpk. Mulyono, S.Pd.I selaku koordinator pembinaan Al-Qur'an pada tanggal 29 Mei 2019 di MAN 1 Malang
} 
kesan formal agar peserta didik lebih nyaman saat bercerita.

Sehubungan dengan persoalan yang sedang di hadapi oleh MAN 1 Malang yaitu beberapa siswa/i nya yang tidak dapat membaca Al-Qur'an, guru BK memiliki pandangan tersendiri yang dinilai dari sisi kehidupan sosial siswa/i MAN 1 Malang. Pasalnya siswa/i yang tidak dapat membaca Al-Qur'an memiliki catatan konsultasi dengan permasalahan yang hampir sama. Tercatat sekitar 10 dari 49 siswa/i yang tidak dapat membaca Al-Qur'an memiliki persoalan sosial. Ada yang merasa kurang mendapatkan perhatian dari keluarga terutama orang tua sehingga mereka tidak memiliki motivasi penuh dalam belajar, ada yang hidup di lingkungan mayoritas tidak terlalu agamis dan ada yang memiliki masalah dengan teman sejawat sehingga tidak nyaman selama proses belajar di sekolah. ${ }^{50}$

Persoalan yang sedang dialami tersebut diduga sebagai salah satu faktor penyebab siswa/i yang tidak dapat membaca AlQur'an. Dugaan tersebut di dasari dengan pernyataan konsultan yang menceritakan bahwa motivasi belajar agama berkurang karena dukungan dari keluarga yang kurang, sulit belajar agama karena kebanyakan anak usia SMP keatas di lingkungan masyarakatnya sudah tidak mengenyam pendidikan agama, dan minat belajar agama yang kurang karena tidak mendapatkan teman yang sepaham ketika di tempat belajar agama.

Berdasarkan data yang dimiliki oleh madrasah terkait penyebab siswa/i MAN 1 Malang yang tidak mampu membaca AlQur'an, maka pihak madrasah mengadakan bimbingan membaca Al-Qur'an secara khusus. Sebelum melaksanakan bimbingan tersebut, pertama-tama pihak madrasah mendatangkan wali murid yang bersangkutan guna untuk menyelesaikan persoalan kurangnya dukungan dari orang tua. Dalam pertemuan tersebut, pimpinan dan panitia bimbingan membaca Al-Qur'an memberikan pengarahan dan motivasi agar bisa memperhatikan putra putrinya secara khusus. Pihak madrasah berharap agar para orang tua mampu memberikan dukungan kepada anaknya untuk belajar agama, dukungan tersebut dapat berupa pengajaran secara pribadi, pemberian motivasi dan semangat belajar serta dukungan-dukungan yang serupa.

Setelah mengadakan pertemuan dengan wali murid, pihak madrasah memanggil siswa/i yang tidak dapat membaca AlQur'an secara khusus tanpa memberitahukan kepada seluruh sekolah tentang tujuan pemanggilannya. Setelah siswa/i yang bersangkutan berkumpul di aula MAN 1 Malang, pihak madrasah memberikan pengarahan dan memotivasi siswa/i agar memiliki semangat belajar membaca Al-Qur'an dengan baik dan benar. Pihak madrasah memberikan pengarahan khusus yang bertujuan untuk meningkatkan minat belajar membaca AlQur'an tanpa di dasari rasa terpaksa. Rasa terpaksa tersebut dapat muncul karena perasaan malu, tidak adanya minat belajar, kurangnya motivasi belajar dan lain sebagainya.

Bimbingan membaca Al-Qur'an dimulai terhitung sejak bulan Agustus, yakni selang 2 bulan setelah masuk tahun ajaran 2018/2019. Siswa/i MAN 1 Malang yang tidak dapat membaca Al-Qur'an dibimbing oleh beberapa ustadz/ustadzah dari pondok di sekitar MAN 1 Malang.

50 Hasil wawancara dengan Ibu Dwi Sesanti Wilujeng selaku guru Bimbingan Konseling pada tanggal 29 Mei 2019 di MAN 1 Malang 
Waktu yang digunakan untuk bimbingan selama kurang lebih 90 menit, terhitung sejak jam 06.45 - 08.15 WIB. Alasan menggunakan jam tersebut adalah untuk menghindari rasa minder yang timbul jika bimbingan dilakukan ketika jam efektif pelajaran. Di khawatirkan jika siswa/i yang mendapat bimbingan merasa kurang nyaman dan malu kepada temanteman sekelasnya karena masih belum bisa membaca Al-Qur'an dengan baik. Oleh sebab itu bimbingan membaca Al-Qur' an di lakukan di musholla MAN 1 Malang ketika sebelum masuk jam pelajaran pertama. Selain untuk menghindari rasa minder yang timbul, siswa/i yang mendapatkan bimbingan tidak akan ketinggalan mata pelajaran dikelas..$^{51}$

Dari 49 siswa/i bimbingan Al-Qur'an dibentuk menjadi 9 kelompok yang terdiri dari 4-5 anggota dan kemudian mendapatkan bimbingan khusus dari 1 pengajar. Metode bimbingan yang akan diterapkan diserahkan sepenuhnya kepada para pengajar, yang penting dapat mencapai target yaitu siswa/i dapat membaca Al-Qur'an dengan fashih serta mampu menerapkan ilmu tajwid dan gharib. Setelah bimbingan berjalan selama satu bulan, pengajar dan pihak madrasah melakukan evaluasi terkait sejauh mana peningkatan yang dialami oleh siswa/i bimbingan.

Selama satu bulan sekali, pihak madrasah melakukan uji ulang membaca Al-Qur'an kepada siswa/i yang sudah mendapatkan bimbingan guna mengetahui sejauh mana perkembangan yang dialami peserta didik dengan adanya bimbingan khusus membaca Al-Qur'an. Ada sekitar 5 anak yang sudah lolos dan dikategorikan sebagai siswa/i yang sudah mampu membaca Al-Qur'an dengan baik dan

51 Hasil pengarahan ketika pertemuan guru bimbingan Al-Qur'an oleh Bu Sri Budi selaku panitia benar. Dengan adanya bimbingan khusus membaca Al-Qur'an, siswa/i merasa sangat terbantu meskipun awalnya beberapa dari mereka merasa terpaksa untuk mengikuti bimbingan tersebut.

Sejauh ini bimbingan membaca AlQur'an masih terus berjalan. Selain bimbingan Al-Qur'an, pihak madrasah dan di bantu dengan guru BK terus melakukan upaya menanamkan motivasi belajar agama yang tinggi agar jiwa religius dalam diri siswa/i MAN 1 Malang tercipta sesuai dengan program yang ditetapkan dan sesuai dengan tuntutan masyarakat luas.

\section{SIMPULAN}

Pada pendidikan formal yang berbasis madrasah, pelajaran keagamaan akan banyak dijumpai dibandingkan dengan sekolah pada umumnya. Pendidikan Agama Islam dipelajari secara detail dalam bentuk mata pelajaran Fiqh, Aqidah Akhlaq, Sejarah Islam, Al-Qur'an Hadist dan Bahasa Arab. Dalam beberapa mata pelajaran tersebut siswa/i akan banyak menjumpai literatur agama yang berbahasa Arab, selain itu siswa/i madrasah akan mengkaji sumber pengetahuan berdasarkan Al-Qur'an dan Hadist.

Semua elemen dalam lingkungan sosial siswa/i secara tidak langsung melakukan internalisasi. Internalisasi merupakan penanaman nilai-nilai sosial yang dilakukan oleh lingkungan sekitar sehingga membentuk nilai-nilai dalam diri individu. Proses internalisasi pada siswa/i yang tidak dapat membaca Al-Qur'an merupakan sebuah faktor penyebab tingkat kemampuan dalam membaca Al-Qur'an. Berdasarkan hasil observasi dana wawancara, terdapat 4 faktor lingkungan sosial dalam kemampuan membaca AlQur'an siswa/i MAN 1 Malang.

inti bimbingan membaca Al-Qur'an pada bulan Agustus di Musholla Al-Hamid MAN 1 Malang 
166 | Mashdar : Jurnal Studi al-Quran dan Hadis, Vol.2 No.2 2020 (143-168)

Dialektika realitas subjektif dalam sosiologi pengetahuan membentuk sebuah realitas objektif yang berbunyi bahwa tuntutan masyarakat untuk melahirkan individu yang menjalankan syariat agama tercermin dalam visi misi MAN 1 Malang yaitu membentuk siswa/i yang religius dan menjalankan tuntutan agama dalam kehidupan sehari-hari. Visi misi tersebut akhirnya mempengaruhi bagaimana MAN 1 akan dijalankan. Mengetahui adanya fenomena yang menghambat jalannya visi dan misi yang sudah disahkan dalam Surat Keputusan, maka ada beberapa upaya yang dilakukan oleh MAN 1 Malang. Upaya tersebut dijabarkan dalam perspektif sosiologi penegtahuan menggunakan 3 dialektika, yaitu obyektivikasi, internalisasi dan eksternalisasi.

Upaya yang dilakukan oleh sekolah guna menghadapi problematika yang ada yaitu dengan program habituasi. Siswa/i MAN 1 dibiasakan untuk menerapkan ajaran agama dalam kehidupan sehari-hari dimulai dari lingkungan sekolah. Program tersebut terealisasi dalam bentuk : 1) Mengaji selama 15 menit sebelum memulai jam pertama 2) Berdo'a sebelum dan seusai KBM 3) Sholat berjama'ah 4) Mengisi Kultum 5) Maulid diba'iyah bagi siswi yang berhalangan sholat. Karena pada program mengaji terdapat hambatan berupa siswa/i yang tidak dapat membaca Al-Qur'an maka sekolah mengupayakan adanya bimbingan khusus membaca Al-Qur'an bagi siswa/i yang tidak mampu.

\section{DAFTAR PUSTAKA}

Yusuf, Chairul. 2008. Budaya Sekolah dan Mutu Pendidikan. Jakarta : PT Cita Satria

Hasbullah. 1999. Dasar-dasar Ilmu Pendidikan. Jakarta : Raja Grafindo Persada
Ahmadi, Abu. 1982. Sosiologi Pendidikan. Surabaya : PT Bina Ilmu

Al-Munawwar, Said Agil Husain. 2002. AlQur'an Membangun Tradisi Keshalehan Hakiki. Jakarta : Ciputat Pers

Manna, Al-Qattan. 2009. Studi Ilmu-ilmu AlQur'an. Surabaya : CV Rasma Putra

B. Suryosubroto. 2009. Proses Belajar Mengajar di Sekolah. Jakarta : Rineka Cipta

Dalman. 2013. Keterampilan Membaca. Jakarta : PT Raja Grafindo Persada

Ash Shiddiqy, Hasbi. 1992. Sejarah dan Pengantar Ilmu Al-Qur'an/Tafsir. Jakarta : PT Bulan Bintang

Soenarto, Ahmad. 2009. Pelajaran Tajwid Praktis dan Lengkap. Jakarta : Bintang Terang

Alam, Dt. Tombak. 1995. Ilmu Tajwid Populer 17 Kali Pandai. Jakarta : Bumi Aksara

Humam, As'ad. 2005. Cara Cepat Belajar Tajwid Praktis. Yogyakarta : Tim Tadarus AMM

Munir, Ahmad dan Sudarsono. 1994. Ilmu Tajwid dan Seni Baca Al-Qur'an. Jakarta : PT Rineka Cipta

Hasani, Hidayatullah dkk. 2007. Kaidahkaidah Tajwid dalam membaca AlQur'an. Yogyakarta : Lembaga Pendidikan Al-Qur'an Masjid Syuhada' 
Syah, Muhibbin. 1995. Psikologi Pendidikan dengan Pendekatan Baru. Bandung : Remaja Rosdakarya

Hamalik, Oemar. 2000. Psikologi Belajar dan Mengajar. Bandung : Sinar Baru Algesindo

Johnson. 1986. Teori Sosiologi Klasik dan Modern. Jakarta : PT Gramedia

Kalidjernih. 2010. Study Kewarganegaraan, Perspektif Sosiologikal dan Politikal. Bandung : Widya Aksara

L. Berger, Peter dan Thomas Luckman. 1990. Tafsir Sosial atas Kenyataan : Sebuah Risalah Tentang Sosiologi Pengetahuan. Jakarta : LP3ES

Rais, Marmawi. 2012. Internalisasi Nilai Integrasi Untuk Menciptakan Keharmonisan Hubungan Antar Etnik. Desertasi pada program pascasarjana PPU Bandung. Tidak di terbitkan, hlm. 10 di akses pada Minggu, 26 Mei 2019
Mujib, Abdul dan Jusuf Mudzakir. 2006. Ilmu Pendidikan Islam. Jakarta : Kencana Prenada Media

Syaodih, Nana. 2013. Metode Penelitian Pendidikan. Bandung : Rosdakarya

Arikunto, Suharsimi. 2006. Manajemen Penelitian. Jakarta : Rineka Cipta

Sugiyono. 2016. Metode Penelitian Pendidikan. Bandung : Alfabeta Bandung

Bungin, Burhan. 20008. Penelitian Kualitatif. Jakarta : Prenada Media Group

Tanzeh, Ahmad. 2009. Pengantar Metode Penelitian. Yogyakarta : Teras,

Sugiyono. 2001. Metode Penelitian Kuantitatif, Kualitatif dan RED. Bandung : Alfabeta

Usman, Husaini. 2006. Manajemen, Teori, Praktek dan Riset Pendidikan. Jakarta : Bumi Aksara 
168 Mashdar : Jurnal Studi al-Quran dan Hadis, Vol.2 No.2 2020 (143-168) 